\title{
Detection of Salmonella typhimurium in chicken meat imported in the local markets of Diwaniya city By using PCR technique
}

\author{
A.A. Saeed K. N. Taher H. A.A. Al-Nassrawi \\ Coll. of Vet. Med./Unive. Of Al-Qadisiyah
}

\begin{abstract}
:
The aim of this study to detected contamination with Salmonella spp. In imported chicken meat in the local markets of Al- Diwaniyia city . to protect health of consumer and Determintion the most contaminated origin with salmonella spp. A toatl of 100 chicken meat samples collected from different origin. The bacteria cultured and isolated in enrichment and selective media. Salmonella isolates were subjected to some biochemical tests show positive productive results H2S .TSI . SIM And its give negative for indole, vo-gs Proskauer and ureas, Biochemical identification was carried out using API 20-E test ..the result showed isolation sample (33155)60\% on bismuth sulphate agar and the results of isolation on chromogenic agar were $87.8 \mid \%(29133)$.according to reading Api20-E system the results of confirmation of isolates 92\%(25126) In this study,( 23) Salmonella isolates were detected by polymerase chain reaction (PCR) by using $16 s$ rRNA and invA gene these primers were selected specifically for the detection of Salmonella to amplify a $406 \mathrm{bp}$ and $558 \mathrm{bp}$ DNA fragments, respectively. Only 7 isolates out of 23 were identified as $S$. typhimurium the results of this study showed the highest percent of s.typhimurim isolates was ( 50\%) (3/6) for India origin and the lowest was Turkish origin
\end{abstract}

\section{Introduction}

Food borne diseases caused typhoid Salmonellosis represent an important public health problem worldwide. It is estimated that approximately $70 \%-80 \%$ of food borne bacterial outbreaks were caused by Salmonella spp. in China (1). In the United States Salmonella infections (approximately 32,000 annually) were reported during 1998-2002 (2). , beef and poultry /chicken meat have been recognized as significant sources of human salmonellosis (3). Salmonella serotypes, $(S$.$) Typhimurium is one of the most$ important agents of food borne Salmonellosis in humans . [4] It was estimated that approximately $75 \%$ of human salmonellosis cases were due to contaminated food products, such as beef, pork, poultry and Chicken products are recognized as an important source molecular methods such as polemear chain reaction (PCR), have shown high sensitivity and specificity for detecting target pathogens, including Salmonella, in different types of foods, and the time required to obtain results can be as short as $12 \mathrm{~h} \mathrm{(5)}$ ) The use of $16 \mathrm{~s} r$ RNAgene or invA gene specific PCR method in most diagnostic and research laboratories is possible and through the molecular basis of Salmonella identification techniques, this method is the simplest and less expensive ( 6) the $16 \mathrm{~S}$ rRNA genes are highly conserved among isolates belonging to the same bacterial species, (7) invA is located on the pathogenicity island 1 of Salmonella spp. encoding proteins of a type (T3SS) III secretion system this gene is highly conserved among the Salmonella spp. and is associated with the adherence and invasion of mammalian cell. 


\section{Material and Methods}

\section{1-Collection of samples}

Chicken samples were collected from different market in al-diwaniyia city with different origin include different trademark ( al-kafeel ,al murad, thighs U.S.A, Turkish Chicken, Chicken JD) the sample transport by ice box about $25 \mathrm{~g}$ from meat sample were placed in $225 \mathrm{ml}$ of enrichment medium tetrathionate broth in microbiological laboratory in veterinary collage for $18-24 \mathrm{~h}$ at $37^{\circ} \mathrm{C}$.. this study took place during the period from December 2011 and carry on June2012.

2- Isolation and identification of salmonella spp.:-

The samples were cultivated on to selective medium such as bismuth sulphate agar and chromogenic agar For identification of salmonella colonies, incubation at $37 \mathrm{c}^{\circ}$ for 18-24 hr samples were subjected to biochemical tests such as (TSI), SulfideIndole- (SIM), (MRVP), Urea, and finally confirmed by using Api20-E system, Colonies that showed biochemical characteristics similar to that of Salmonella spp. were tested by API20-E system and the confirmation was identified by PCR with 16s rRNA and invA genes primers for the detection ofsalmonellaspp

3-Specific Primers Sequence Used for PCR Amplification:

The primers used for the detection specific sequence of $16 \mathrm{~s}$ rRNA gene ribosomal genes of Salmonella spp [8]. And $i n v A$ gene encoding proteins of a type (T3SS) III secretion system [9]These primers are specific for designed in this study by using NCBI Gene Bank and Primer: online and provided by (Bioneer company, Korea) as following Table(1):

Table(1):Specific primers used for the detection specific sequence of $16 s$ rRA gene and invA

\begin{tabular}{|c|c|c|c|}
\hline Sequence & Orientation & Position & $\begin{array}{l}\text { Size of } \\
\text { PCR } \\
\text { product( } \\
\text { bp) }\end{array}$ \\
\hline $\begin{array}{c}\text { CGG.,ACG,GGT,GAG,TAA,TGT } \\
\text {,CT }\end{array}$ & Forward & \multirow[t]{2}{*}{$\begin{array}{l}16 s \\
r R N A\end{array}$} & \multirow{2}{*}{406} \\
\hline $\begin{array}{c}\text { GTT,AGC,CGG,TGC,TTC,TTC, } \\
\text { TG }\end{array}$ & Reverse & & \\
\hline $\begin{array}{c}\text { ATG,CCC,GGT,AAA,CAG.ATG, } \\
\text { ATG,AG }\end{array}$ & Forward & \multirow[t]{2}{*}{$\overline{\text { inVA }}$} & \multirow{2}{*}{558} \\
\hline $\begin{array}{c}\text { CTC,GCC,TTT,GTC,GGT,TTT,A } \\
\text { G }\end{array}$ & Reverse & & \\
\hline
\end{tabular}

\section{4- Polymereas chain reaction PCR}

4.1 Genomic DNA extraction

Salmonella spp. isolates were cultured on brain heart broth for $18-24 \mathrm{~h}$ at $37^{\circ} \mathrm{C}$; the extraction of DNA was performed according to Genomic DNA kit provided by geneaid company (USA ).

\subsection{DNA Amplification:}

The amplified DNA products from Salmonella spp .specific-PCR were analyzed 
with electrophoresis on $1 \%$ agarose gels stained with ethidium bromide and visualized by UV illumination. depending on DNA marker (2000 bp DNA ladder).

4.3 Preparation master mix for Detection of 16s rRNA and inva genes

For the detection of Salmonella spp. and $S$. typhimurium by PCR. The PCR amplification mixture $(20 \mu \mathrm{l})$ which was used for the detection each gene includes 5 $\mu l$ of (PCR PreMix Lyophilized), which provided by Bioneer (Korea .)include: bacterially derived Taq DNA polymerase; dNTPs which include: $400 \mu \mathrm{M}$ of each dATP, dGTP, dCTP, dTTP;
$3 \mathrm{mM}$ of Mgc12; Yellow and blue dyes as loading dye), $5 \mu 1$ of template DNA, $1.5 \mu 1$ of each forwarded and reversed primers and 7. $\mu \mathrm{l}$ pcr water to complete the amplification mixture to $20 \mu \mathrm{l}$. The PCR tubes containing an amplification mixture were transferred to thermocycler and started the program for amplication of the 16s rRNA and invA genes. 30 cycles of PCR, with 1initial denteration 1 cycle $95 \mathrm{C}^{\circ}$ for $\mathrm{I}$ min then $5 \mathrm{~min}$ at $95 \mathrm{C}^{\circ}$ (denaturation), $\quad 30 \quad \mathrm{~s}$ at $55 \quad \mathrm{C}^{\circ}$ (annealing), and $45 \mathrm{~s}$ at $72 \mathrm{C}^{\circ}$ (extension). And 1 cycle for $7 \mathrm{~min}$ at $72 \mathrm{c}^{\circ}$ (final extension

\section{Results}

\subsection{Culture methods :-}

The total percentage of isolation on tetrathionate broth, bismuth sulphate agar, chromogenic agar was 55\% (55/100), $60 \%$ ( $33 / 55), 87.8 \%(33 / 29)$, the highest percent of isolation was from (India origin
) . The colonies of salmonella spp.on chromogenic agar were Variable in size convex and mauve in color. Figure(1) . the Results of isolation salmonella spp. using cultural methods. present in table (2).

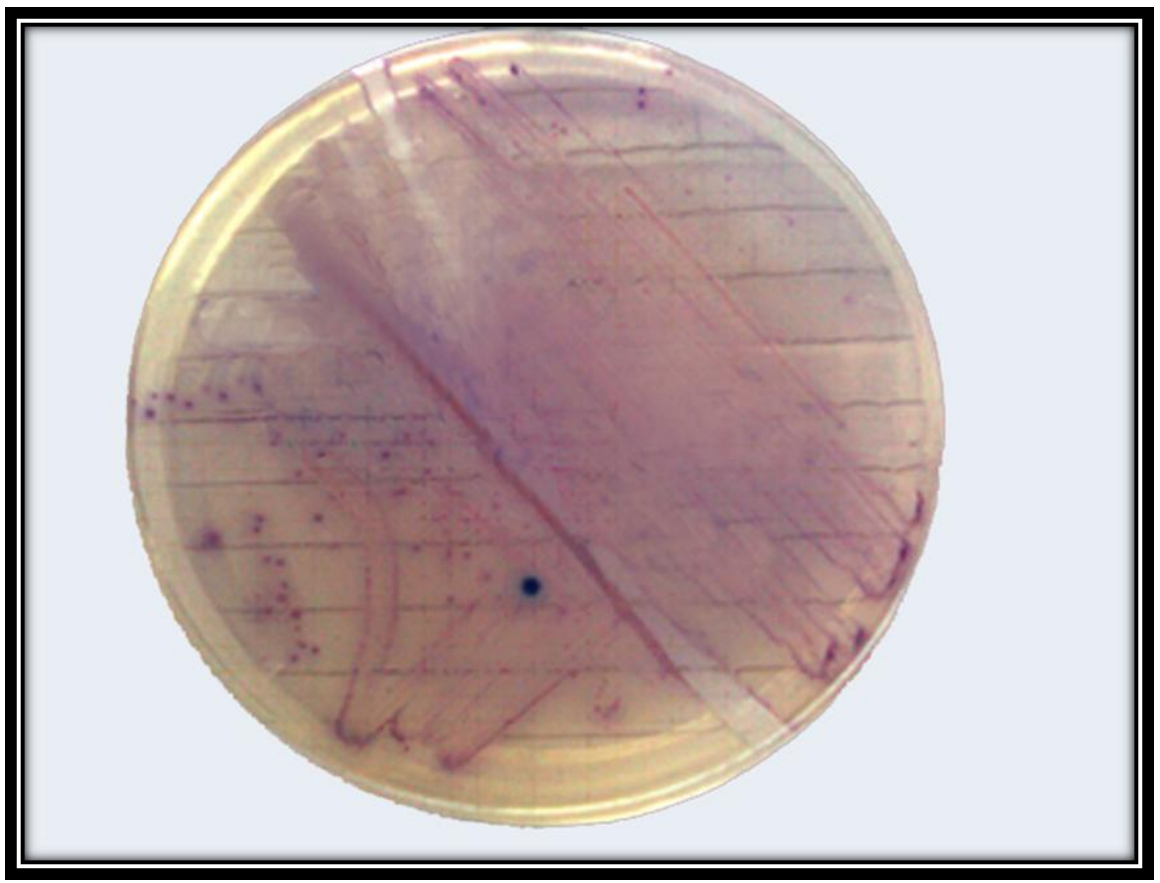

Figeur (1) Colonies of salmonella spp. on chromogenic salmonella agar (The arrow shows variable size and mauve in color. 
Table ( 2 )Results of salmonella spp. Isolation by using culture methods from chicken meat sample.

\begin{tabular}{|c|c|c|c|c|c|c|c|c|c|}
\hline Culture media & \multicolumn{3}{|c|}{$\begin{array}{l}\text { Tetrathionate } \\
\text { broth }\end{array}$} & \multicolumn{3}{|c|}{$\begin{array}{l}\text { Bismuth sulphate } \\
\text { agar }\end{array}$} & \multicolumn{3}{|c|}{ Chromogenic agar } \\
\hline Origin & $\begin{array}{l}\text { No. of } \\
\text { tested } \\
\text { sample }\end{array}$ & $\begin{array}{c}\text { No.of } \\
\text { positive }\end{array}$ & $\%$ & $\begin{array}{l}\text { No.of } \\
\text { tested } \\
\text { sample }\end{array}$ & $\begin{array}{c}\text { No.of } \\
\text { positive }\end{array}$ & $\%$ & $\begin{array}{l}\text { No.of } \\
\text { tested } \\
\text { sample }\end{array}$ & $\begin{array}{l}\text { No.of } \\
\text { positive }\end{array}$ & $\%$ \\
\hline $\begin{array}{l}\text { Jordan } \\
\text { chicken JD }\end{array}$ & 20 & 12 & 60 & 12 & 7 & 58.3 & 7 & 6 & 85.7 \\
\hline $\begin{array}{l}\text { Turkish casken } \\
\text { oglo }\end{array}$ & 20 & 9 & 45 & 9 & 5 & 55.5 & 5 & 5 & 100 \\
\hline Brazil al-kafeel & 20 & 10 & 50 & 10 & 6 & 60 & 6 & 5 & 83.3 \\
\hline India al-murad & 20 & 11 & 55 & 11 & 7 & 63.6 & 7 & 7 & 100 \\
\hline U.S.A. thighs & 20 & 13 & 65 & 13 & 8 & 61.5 & 8 & 6 & 75 \\
\hline Total & 100 & 55 & 55 & 55 & 33 & 60 & 33 & 29 & 87.8 \\
\hline
\end{tabular}

5.2 Confirmatory isolation of salmonella spp.and S.typhimurium by using Api20-E and PCR technique:-

Salmonella isolates were subjected to some biochemical tests show positive productive results $\mathrm{H} 2 \mathrm{~S}$.TSI . SIM And its give negative for indole, vo-gs Proskauer and ureas, The total percentages of these tests $89.6 \%$ (29 \26). And according to the reading of API 20-E system show that 25 isolated positive to API20-Esystem from 26 with percentage 96.1\%.the results in table (3). 
Table (3) Results of Biochemical test and API20-E system .

\begin{tabular}{|l|c|c|c|c|c|c|l|}
\hline \multicolumn{3}{|c|}{ Test } & \multicolumn{3}{c|}{ Aiochemical test } & \multicolumn{3}{c|}{ API20-E system } \\
\hline Sample origin
\end{tabular}

\subsection{Molecular confirmatory detection} using Single plex PCR:-

The confirmed diagnosis of Salmonella spp. were performed by using single plex PCR to detect $16 s$ rRNA gene the total percentage was $92 \%(23 / 25)$ for chicken meat and the higher percent for isolation salmonella spp. by $16 s \quad r R N A$ gene was from al-kafeel and U.S.A thighs
$100 \%$ while the lower percent was from Turkish origin $75 \%$. the total percentage for detect invA gene for S.typyimuirim serotype was $30.4 \%(7 / 23)$. And the highest percent of isolation of S.typyimuirim was $50 \%$ from India origin while the lower was $0 \%$ from Turkish origin.( Figure 2) and ( Figure 3). 


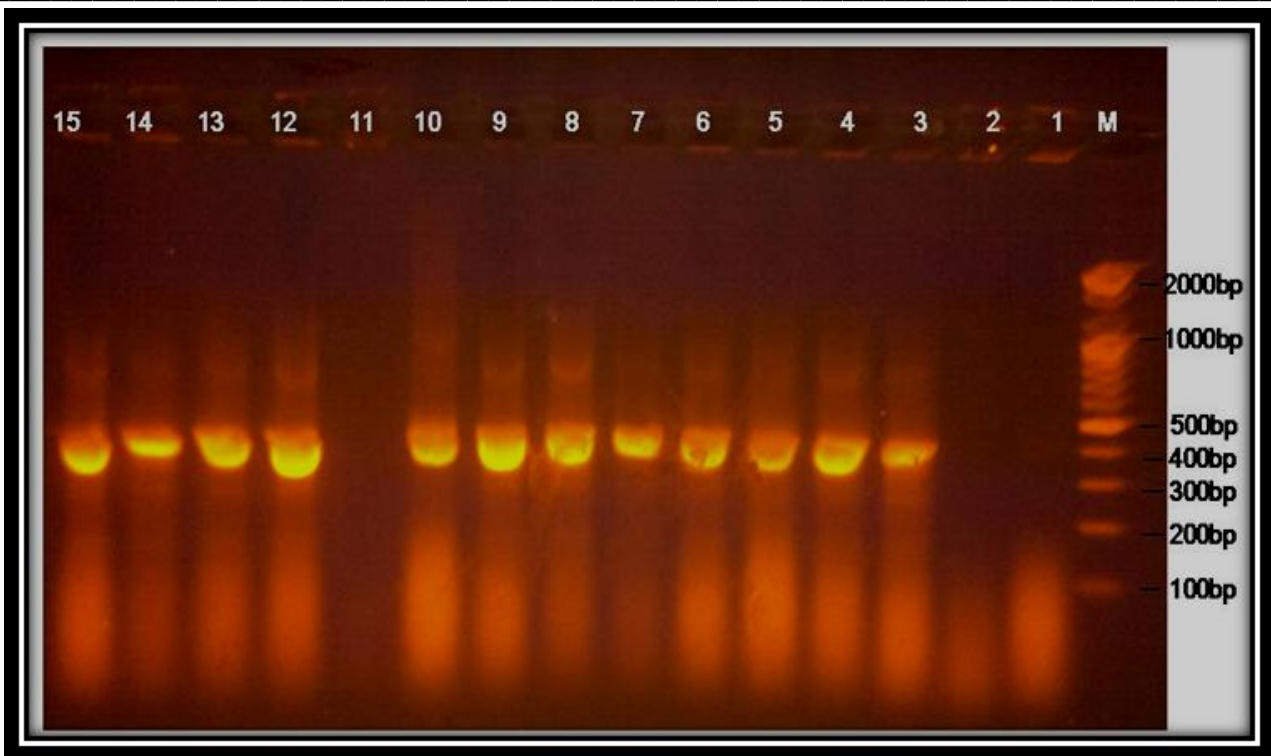

(Figer:- 2)) DNA amplification of a $406 \mathrm{bp}$ of salmonella spp.detecting $16 s \quad r$ RNA gene using singleplex PCR lane 1 control, lane 2,11 negative results ,lane 3,4,5,6,7,8,9,10,12,13,14,15 positive results as salmonella spp. Lane M 2000bp marker (ladder).

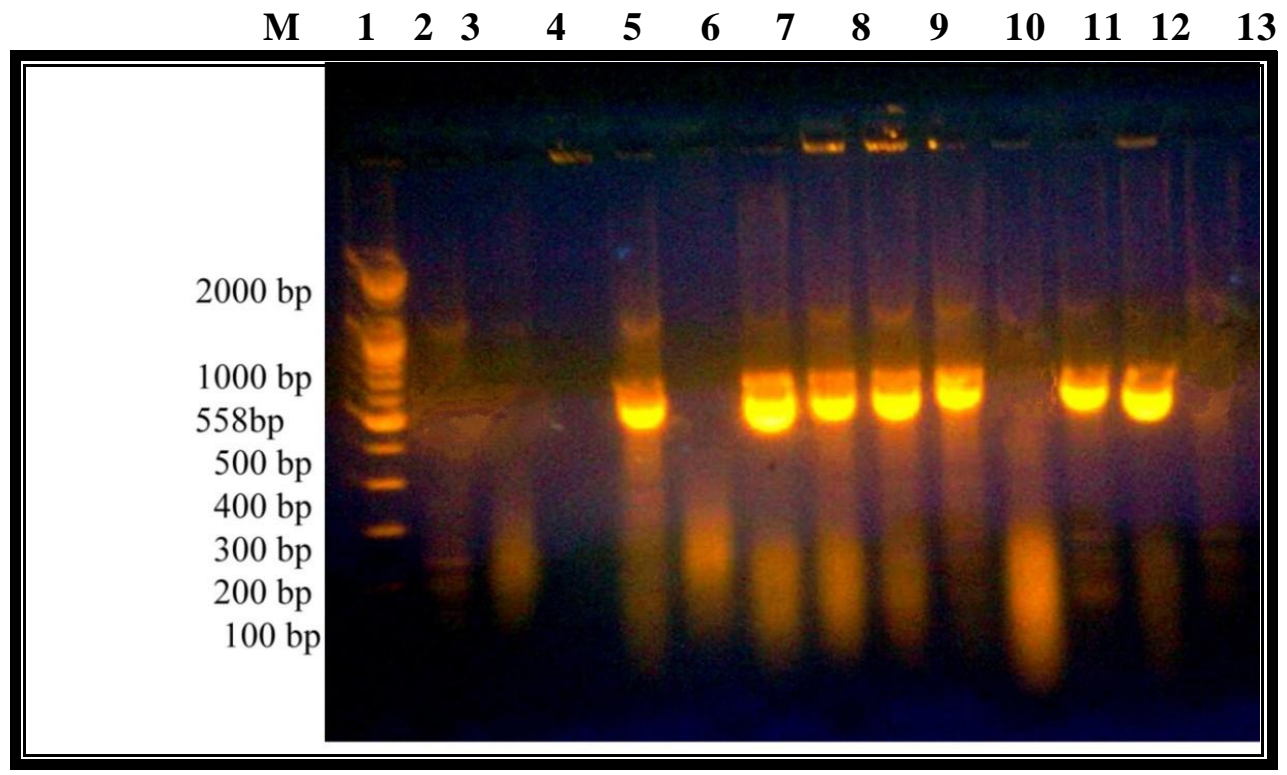

( Figer 3) DNA amplification of a $558 \mathrm{bp}$ of salmonella spp detecting invA gene using singleplex PCR lane 1 conterol results ,lane,4, 6,7,8,9,10,12, positive results as $S$. typhimuirim spp. Lane 2,3 5,13negative result, lane M 2000bp marker (ladder). 
Table (4):- Results of detecting salmonella spp. By Single plex PCR 16s rRNA gene and in $v A$ gene

\begin{tabular}{|c|c|c|c|c|c|c|c|}
\hline \multicolumn{2}{|c|}{ Sample origin } & \multicolumn{3}{|c|}{$\begin{array}{l}\text { Single plex PCR } \\
\text { Detect } 16 s \quad r R A \text { gene }\end{array}$} & \multicolumn{3}{|c|}{$\begin{array}{l}\text { Single plex PCR } \\
\text { detect inVA gene }\end{array}$} \\
\hline Origin & trademark & $\begin{array}{l}\text { No. tested } \\
\text { sample }\end{array}$ & $\begin{array}{l}\text { No. of } \\
\text { positive }\end{array}$ & $\%$ & $\begin{array}{c}\text { No. } \\
\text { tested } \\
\text { sample }\end{array}$ & $\begin{array}{l}\text { No. of } \\
\text { positive }\end{array}$ & $\%$ \\
\hline Jordan & chickenJD & 5 & 4 & 80 & 4 & 1 & 25 \\
\hline Turkish & casken oglo t & 4 & 3 & 75 & 3 & 0 & 0 \\
\hline Brazil & al-kafeel & 4 & 4 & 100 & 4 & 1 & 25 \\
\hline India & al-murad & 6 & 6 & 100 & 6 & 3 & 50 \\
\hline U.S.A. & thighs & 6 & 6 & 100 & 6 & 2 & 33.3 \\
\hline Total & & 25 & 23 & 92 & 23 & 7 & 30.4 \\
\hline
\end{tabular}

\section{Disscuse}

Chicken meat, is one of the most important sources and a good compromise for the growth and transfer of Salmonella spp. and causing cases Food poisoning and that its presence in the fresh chicken meat, chilled and not well cooked Pose a threat to public health and a source of contamination of food through the stages food during preparation stages and food preparation.(10) . To determine the level of contamination with salmonella spp. in imported poultry meat in the markets of the city of Al- Diwaniya, this study included several methods to isolated and detected a hundred samples of chicken meat from different origins the results of isolation on
Tetrathionat broth as enrichment media were $55 \%(55 / 100)$ this results came compatible with ( 11) which his result $(58.6 \%)$ from chicken meat when used Tetrathionat broth as pre enrichment media $42{ }^{\circ} \mathrm{C}$, and higher than those obtained by (12) (48\%.) )and, (13) ( $31.4 \%$ ) . several bacteriological selective media have been used to isolating Salmonella spp. them bismuth sulphate agar. Where results of isolation on this media $60 \%(33 / 55)$ and this results higher than (14) when use Bismuth sulphate agar to isolated salmonella from a ported chicken in market of Baghdad city which his results was $24.76 \%$. chromogenic agar 
considers One of the latest techniques that used in recent decade to rapid isolation of pathogenic agent in water and food is. These media are very specific and their component act as substrate for specific enzyme and depending on enzyme exhibit special color. (15) . salmonella spp. Was isolated (29/33) samples when inoculation on this agar with percent (87.8\%) which was significantly higher what has been reached in the study (16). the cause of this difference in the percent of isolated salmonella between studies due to the difference in the number of samples examined and health standards in the massacres . the results of isolation in chromogeninc agar were refer to the accuracy and specificity of this media for bacterial isolation of Salmonella spp. in compare with other diagnosis methods chromogenic media have more advantage and can be an appropriate alternative for conventional and routine procedure. Chromogenic media eliminate the need of subculture in addition to shortest period of time pathogenic agent can be identified.

Biochemical test and Api-20 E system :-

The API 20-E diagnostic, which detects 20 biochemical reactions, is a traditional method for the identification of Salmonella enterica and other Enterobacteriaceae (17) . the present study shows that the total percentage of isolation salmonella spp. According to the reading of API 20-E system the confirmation of 25 isolates were done from 27 with percentage 92.5 $\%$ and this percentage was very closer to ( 18) that was his result 99\%) when evaluated API 20-E as indicator for salmonella enterica. And this results show that API 20 E system is a universal method supported in most laboratories global diagnostic the results don't show any difference or variation in the characteristics of bacteria (bacteriological .biochemical characteristic) and this gives us more confidence for all subsequent steps related to this research .

\section{Molecular confirmatory detection of salmonella spp.}

By using Single plex PCR Technique :

Traditional methods for detection of Salmonella in food have included culturing the food item on selective media followed by characterization of suspect colonies with additional biochemical tests and immunoassays. In general, this process requires multiple days for successful identification of the pathogen. To overcome the protracted nature of traditional detection methods, and to enhance the sensitivity and specificity of detection, a number of molecular diagnostic methods have been developed, including methods that utilize Polymerase Chain Reaction (PCR). The use of $16 \mathrm{~s} r$ RNAgene or invA gene specific PCR method in most diagnostic and research laboratories is possible and through the molecular basis of Salmonella identification techniques, this method is the simplest and less expensive (19). the results salmonella spp. detection by using 16s $r$ RNA gene in present study from chicken meat samples were $92 \%(23 / 25)$ Table (16) than the percent of isolation serotype S.typhimurium from these sample were $30.4 \%(7 / 23)$, the results agreed with previous study (20), (21) obtained the ratio of contamination of salmonella in chicken meat 36\%(9/25) , $38 \%$ respectively when using invA gene .. The ability of Salmonella specific primers to detect Salmonella species rapidly and accurately in the present study is primarily due to the primer sequences that are selected from the gene invA of $S$. typhimurium as reported by (22) The amplified PCR products which were carried out using the universal bacterial $16 s r R N A$ and invA primers and visualized by UV illumination showed the expected bands of about $406 \mathrm{bp}$ Figure (6) $558 \mathrm{pb}$ Figure (7) The results demonstrated a correct genus identification of examined Salmonella isolates. The final results of 
present study were $23 \%(23 / 100)$ it closer to (14) which his result $30 \%$ while his result to isolated S.typhimurim were $7.7 \%(2 / 26)$, also similar to previous studies obtained by (23) (20\%), While lower than (24) that his result $60 \%$ of 192 chicken samples. This variation of results between studies may be associated with different factors such as, season of the study, number of samples and the methods applied. The predominant serotypes differ indifferent countries, hygienic conditions in storage and cross contamination during transport .

\section{References}

1-Wong, D. M. A; Hald, T.;Wolf, P.J.; Swanenburg, M. (2002). Epidemiology and control measures for Salmonella in pigs and pork, Livestock Production Science,.76, (3) :215-222

2-Lynch, M.; Painter, J.; Woodruff, R.; and Braden, C.( 2006). Surveillance for food born disease outbreaks United States, 1998-2002. Surveillance Summaries 55:134.

3- Magistrali, C.; Dionisi, A.M.; Curtis, P.D.; $\quad$ Cucco, L.,;Vischi, O.;Scuota, S., Zicavo, A.; and Pezzotti G.( 2008). Contamination of Salmonella spp. in a pig finishing herd, from the arrival of the animals to the slaughterhouse.J. Vet. Scie.,85, 204-207.

4-Ferretti R,Mannazzu I, Cocolin L, Comi G, Clementi F. 2001. Twelve-hour PCR-basedmethod for detection of Salmonella spp. in food. Appl Environ Microbiol 67:977-980

5- Mead, P.S; Slutsker L.; Dietz V.;McCaig L.F; Bresee J.S;Shapiro C.; Griffin P,M; and Tauxe RV.1999 Food-related illness and death in the United States. Emerg Infect Dis, 5, 607625.

6- White ,P.; Meglli, K.; Collins, D.; and Gormely, E. (2002). The prevalence and PCR detection of Salmonella contamination in raw poultry. Vet. Microbiol., 89: 5360.
7-Baay; M.F.; and Veld, J.H.;(1993) . Alternative antigens reduce crossreactions in an ELISA for the detection of Salmonella enteritidis in poultry. J Appl Bacteriol, 74, 243-247.

8-. Galán, J. E.; and. Curtiss, R . ( 1997). Cloning and molecular characterization of genes whose products allow Salmonella typhimurium to penetrate tissue culture cells. Proc. Natl. Acad. Sci. USA 86:6383-6387.

9- Woese, C.R. ;(1987 ). Bacterial evolution. Microbiol. Rev., 51,221-271

10- Ailsa,D.H. (2003).Food borne microorganism of public health significance. $\quad 6^{\text {th }}$ ed.,AIFST.209255.

11-Vera, L.M.; Ricardo R.; Lina, C. A.; Silva,M.G. (2005) evaluation of three enrichment broths and five plating media for salmonella detection in poultry Brazilian Journal of Microbiology (36):147150

12 -Pietzsch, O. and Burse, M. (1984) Media for Salmonella. Inter. J. Food, Microbiol., 26: 117-131.

13- Arroyo, G. and Arroyo, J.A. (1995) . Efficiency of different enrichment and isolation procedures for the detection of Salmonella serotypes in edible offal. Journal of Applied Bacteriology., 79: 360-367.

14 - Dhaher , F. H; Awni, M. N; Mahmood M.M; and Jamil H. S. (2011) Public Health and Food Safety Lab.I Ministry of 


Agriculture Isolation and

Diagnosis of Salmonella in

Animal Origin Food, Import feed in Baghdad Local Markets and Local Poultry Farms..(3) 2011.

15- Tavakoli,H., Bayat,M.; Kousha, A.,and. Panahi ,P. (2008).The Application of Chromogenic Culture Media for Rapid Detection of Food and Water Borne Pathogen AmericanEurasian J. Agric. \& Environ. Sci, 4 (6): 693-698

16 -Nancy ,D.; vicki,R., kircher,S.; patty ,P.; and krista sturm . (2005)evaluation of BBL $^{\mathrm{TM}}$ chromagar $^{\mathrm{TM}}$ salmonella: AOAC performance tested methods diagnostics $\bullet 7$ loveton circle $\bullet$

17-Koneman, E. W.; Allen, S. M.; Janda, D. W. ; Schreckenberger, P. C. and Winn, W. C. .(1997). The Enterobacteriaceae,. Color atlas and textbook of diagnostic microbiology. Lippincott-Raven Publishers, Philadelphia, 171-252

18-Nucera, D. M.; Maddox, C. W.; HoienDalen, P. and Weigel, R. M. (2006). Comparison of API 20E and invA PCR for identification of Salmonella enterica isolates from swine production units. J. Clin. Microbiol. 44( 9) : 33883390.

19 - White ,P.; Meglli, K.; Collins, D.; and Gormely, E.; (2002). The prevalence and PCR detection of Salmonella contamination in raw poultry. Vet. Microbiol., 89: 5360.
20 -Raafat H., Sohaila F., Hassan, A., Ashraf M.Abd El-Malek; Moemen, A. and Elsayh,K.H.I.(2011 ). Detection and identification of Salmonella species in minced beef and chicken meats by using Multiplex PCR in Assiut city Vet.world., 4 (1):5-11.

21-Darwin, K.H. and Miller, V.L. (1999). Molecular basis of the interaction of Salmonella with the intestinal mucosa. Clin. Microbiol. Rev., 12: 405-428.

22-Harrison, W. A.;Griffith, D. ; Tennant C. J.; and. Peters, A. C.; (2001). Incidence of Campylobacter and Salmonella isolated from retail chicken and associated packaging in South Wales. Lett. Appl. Microbial. 33:450-454

23-Lammerding, A.M.; Garcia, M.M.; Mann, E.D.; Robinson, Y.; Dorward, W.J.; Truscott, R.B.; and Tittiger, F.(1988) . Prevalence of Salmonella and thermophilic Campylobacter in fresh pork, beef, veal and poultry in Canada. J. Food. Prot. 51, 4752.

24 - Carraminana, J.J.; Yanguela, J.; Blanco, D.; Rota, C.; Agustin, A.I.; Arino, A.;and Herrera, A.;(1997). Salmonella incidence and distribution of serotypes throughout processing in a Spanish poultry slaughterhouse. Journal of Food Protection 60: 1312-1317. 


\section{عزل وتثخيص جرثومة السالمونيلا تايفيميوريم من لحوم الدواجن المستوردة في

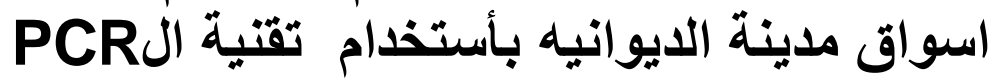

$$
\begin{aligned}
& \text { أصيل عبد الرضا سعيد كريم ناصر طاهر هدى عبد الهادي النصر اوي } \\
& \text { كلية الطب البيطري \جامعة القادسية }
\end{aligned}
$$

\section{الخلاصة}

الهدف من هذه الدراسة هو الكثف عن التلوث بجرثومة . salmonella spp في عينات لحوم الدواجن

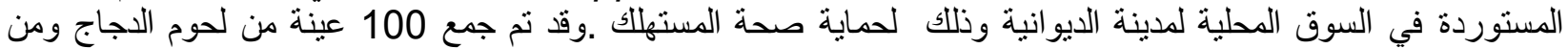

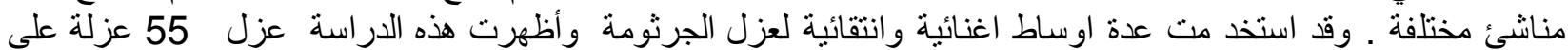

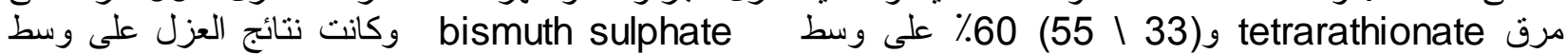
هز chromogenic

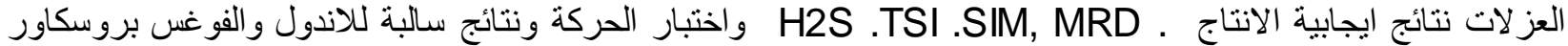

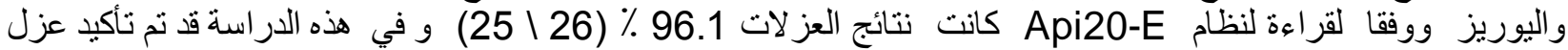

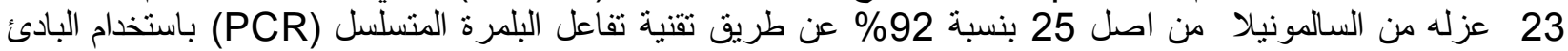

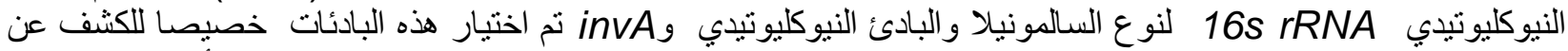

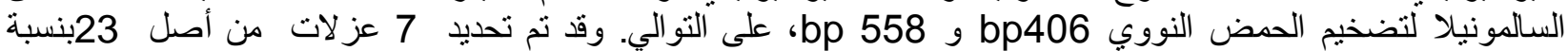

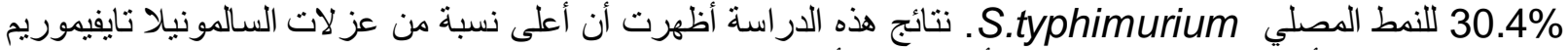
كانت 50\% للمنشأ الهندي (316) و اقل منشأ تلوثا المنشأ التركي. 